\title{
Triggering of Erythrocyte Cell Membrane Scrambling by Emodin
}

\author{
Morena Mischitellia,b Mohamed Jemaà ${ }^{a}$ Mustafa Almasrya ${ }^{a}$ Caterina Faggiob \\ Florian Lang ${ }^{\mathrm{a}, \mathrm{c}}$ \\ aDepartment of Cardiology, Cardiovascular Medicine and Physiology, \\ Eberhard-Karls-University of Tuebingen, Tuebingen, Germany; 'bepartment of Chemical, Biological, \\ Pharmaceutical and Environmental Sciences-University of Messina Viale Ferdinando Stagno d'Alcontres \\ S. Agata-Messina, Italy; 'Department of Molecular Medicine II, Heinrich Heine University Düsseldorf, \\ Germany
}

\section{Key Words}

Phosphatidylserine $\bullet$ Cell volume $・$ Eryptosis $•$ Oxidative stress $\bullet$ Calcium $\bullet$ Emodin

\begin{abstract}
Background/Aims: The natural anthraquinone derivative emodin (1,3,8-trihydroxy-6methylanthraquinone) is a component of several Chinese medicinal herbal preparations utilized for more than 2000 years. The substance has been used against diverse disorders including malignancy, inflammation and microbial infection. The substance is effective in part by triggering suicidal death or apoptosis. Similar to apoptosis of nucleated cells erythrocytes may enter suicidal erythrocyte death or eryptosis, characterized by cell shrinkage and cell membrane scrambling with phosphatidylserine translocation to the erythrocyte surface. Signaling involved in the triggering of eryptosis include increase of cytosolic $\mathrm{Ca}^{2+}$ activity $\left(\left[\mathrm{Ca}^{2+}\right]_{\mathrm{i}}\right)$, oxidative stress and ceramide. The present study aimed to test, whether emodin induces eryptosis and, if so, to elucidate underlying cellular mechanisms. Methods: Phosphatidylserine abundance at the cell surface was estimated from annexin-V-binding, cell volume from forward scatter, $\left[\mathrm{Ca}^{2+}\right]_{i}$ from Fluo3-fluorescence, ROS formation from DCFDA dependent fluorescence, and ceramide abundance utilizing specific antibodies. Results: Exposure of human erythrocytes for 48 hours to emodin $(\geq 10 \mu \mathrm{M})$ significantly increased the percentage of annexin-V-binding cells, and at higher concentrations $(\geq 50 \mu \mathrm{M})$ significantly increased forward scatter. Emodin significantly increased Fluo3-fluorescence ( $\geq 10 \mu \mathrm{M})$, DCFDA fluorescence $(75 \mu \mathrm{M})$ and ceramide abundance $(75 \mu \mathrm{M})$. The effect of emodin on annexin-V-binding was significantly blunted but not abolished by removal of extracellular $\mathrm{Ca}^{2+}$. Conclusions: Emodin triggers phospholipid scrambling of the erythrocyte cell membrane, an effect at least in part due to stimulation of $\mathrm{Ca}^{2+}$ entry and paralleled by oxidative stress and ceramide appearance at the erythroctye surface.




\section{Introduction}

The natural anthraquinone emodin (1,3,8-trihydroxy-6-methylanthraquinone) [1] is an active component of several Chinese medicinal herbs in use for more than 2000 years [2]. Effects of emodin include stimulation of diuresis [1], laxation [3], and vasodilation [1], as well as inhibition of bacterial/viral infection [1, 2, 4], peptic ulcers [1], inflammation [1, 2], and malignancy [1-3, 5-41].

The efficacy against cancer is at least in part due to stimulation of tumor cell apoptosis $[3,5-7,16,20,22,27,38,41-66]$. Molecular mechanisms involved include tyrosine kinases $[3,31]$, casein kinase II [1], protein kinase C [47], AKT/mTOR $[1,28,62], \mathrm{NF}-\kappa \mathrm{B}[1,67,68]$, HIF-1 $\alpha$ [1], STAT3 [1, 59], p53 [1, 21, 23, 32, 54], Wnt signaling [69], Bcl-2/Bax [21, 26, 28], mitochondria [38, 44, 45, 49, 51, 57, 63, 64], oxidative stress [21, 23, 32, 49, 57, 61, 70], and endoplasmic reticulum stress [38].

Despite their lack of mitochondria and nuclei, erythrocytes may enter apoptosis-like suicidal death or eryptosis [71]. Hallmarks of eryptosis are cell shrinkage [72] and cell membrane scrambling with translocation of phosphatidylserine to the cell surface [71]. Signaling involved in the stimulation of eryptosis includes increase of cytosolic $\mathrm{Ca}^{2+}$ activity $\left(\left[\mathrm{Ca}^{2+}\right]_{\mathrm{i}}\right)[71]$, ceramide [73], oxidative stress [71], caspases [71, 74, 75], casein kinase $1 \alpha$, Janus-activated kinase JAK3, protein kinase C, and p38 kinase. Signaling inhibiting eryptosis includes nitric oxide [71], AMP activated kinase AMPK [71], cGMP-dependent protein kinase [71], PAK2 kinase [71], and sorafenib/sunitinib sensitive kinases [71]. Eryptosis is triggered by energy depletion [71], and a large variety of xenobiotics [71, 76-117].

The present study tested, whether emodin is capable to stimulate eryptosis. To this end, erythrocytes were isolated from healthy volunteers, exposed to emodin and analysed by flow cytometry to determine phosphatidylserine surface abundance, cell volume, $\left[\mathrm{Ca}^{2+}\right]_{i}$, ROS formation, and ceramide abundance.

\section{Materials and Methods}

\section{Erythrocytes, solutions and chemicals}

Fresh Li-Heparin-anticoagulated blood samples were kindly provided by the blood bank of the University of Tübingen. The study is approved by the ethics committee of the University of Tübingen (184/2003 V). The blood was centrifuged at $120 \mathrm{~g}$ for $20 \mathrm{~min}$ at $21^{\circ} \mathrm{C}$ and the platelets and leukocytes-containing supernatants were disposed. Erythrocytes were incubated in vitro at a hematocrit of $0.4 \%$ in Ringer solution containing (in $\mathrm{mM}) 125 \mathrm{NaCl}, 5 \mathrm{KCl}, 1 \mathrm{MgSO}_{4}$, $32 \mathrm{~N}$-2-hydroxyethylpiperazine-N-2-ethanesulfonic acid (HEPES; pH 7.4), 5 glucose, and $1 \mathrm{CaCl}_{2}$, at $37^{\circ} \mathrm{C}$ for $12-72$ hours. Where indicated, emodin (Sigma Aldrich, Hamburg, Germany) was added to the Ringer solution, or $\mathrm{CaCl}_{2}$ was removed and $0.5 \mathrm{mM}$ EGTA added to achieve nominally $\mathrm{Ca}^{2+}$ free solutions.

\section{Annexin-V-binding and forward scatter}

After incubation under the respective experimental condition, a $150 \mu \mathrm{l}$ cell suspension was washed in Ringer solution containing $5 \mathrm{mM} \mathrm{CaCl}_{2}$ and then stained with Annexin-V-FITC (1:200 dilution; ImmunoTools, Friesoythe, Germany) in this solution at $37^{\circ} \mathrm{C}$ for 15 min under protection from light. The annexin-Vabundance at the erythrocyte surface was subsequently determined on a FACS Calibur (BD, Heidelberg, Germany). Annexin-V-binding was measured with an excitation wavelength of $488 \mathrm{~nm}$ and an emission wavelength of $530 \mathrm{~nm}$. A marker (M1) was placed to set an arbitrary threshold between annexin-V-binding cells and control cells. The same threshold was used for untreated and emodin treated erythrocytes. A dot plot of forward scatter (FSC) vs. side scatter (SSC) was set to linear scale for both parameters. The threshold of forward scatter was set at the default value of " 52 ".

\section{Hemolysis}

For the determination of hemolysis, the samples were centrifuged $(10 \mathrm{~min}$ at $2000 \mathrm{rpm}$, room temperature) after incubation under the respective experimental conditions and the supernatants were harvested. As a measure of hemolysis, the hemoglobin $(\mathrm{Hb})$ concentration of the supernatant was 


\section{Cellular Physiology Cell Physiol Biochem 2016;40:91-103

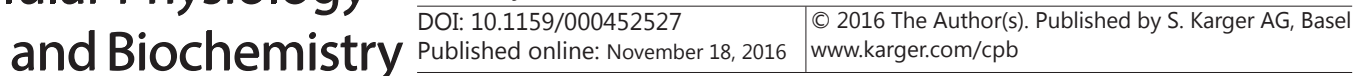 \\ Mischitelli et al.: Emodin-Induced Eryptosis}

determined photometrically at $405 \mathrm{~nm}$. The absorption of the supernatant of erythrocytes lysed in distilled water was defined as $100 \%$ hemolysis.

Intracellular $\mathrm{Ca}^{2+}$

After incubation, erythrocytes were washed in Ringer solution and loaded with Fluo-3/AM (Biotium, Hayward, USA) in Ringer solution containing $5 \mathrm{mM} \mathrm{CaCl}_{2}$ and $5 \mu \mathrm{M}$ Fluo-3/AM. The cells were incubated at $37^{\circ} \mathrm{C}$ for $30 \mathrm{~min} . \mathrm{Ca}^{2+}$-dependent fluorescence intensity was measured with an excitation wavelength of 488 $\mathrm{nm}$ and an emission wavelength of $530 \mathrm{~nm}$ on a FACS Calibur.

Reactive oxidant species (ROS)

Oxidative stress was determined utilizing 2',7'-dichlorodihydrofluorescein diacetate (DCFDA). After incubation, a $150 \mu$ suspension of erythrocytes was washed in Ringer solution and stained with DCFDA (Sigma, Schnelldorf, Germany) in Ringer solution containing DCFDA at a final concentration of $10 \mu \mathrm{M}$. Erythrocytes were incubated at $37^{\circ} \mathrm{C}$ for $30 \mathrm{~min}$ in the dark and washed two times in Ringer solution. The DCFDA-loaded erythrocytes were resuspended in $200 \mu$ l Ringer solution and ROS-dependent fluorescence intensity was measured at an excitation wavelength of $488 \mathrm{~nm}$ and an emission wavelength of $530 \mathrm{~nm}$ on a FACS Calibur (BD).

\section{Ceramide abundance}

For the determination of ceramide, a monoclonal antibody-based assay was used. To this end, cells were stained for 1 hour at $37^{\circ} \mathrm{C}$ with $1 \mu \mathrm{g} / \mathrm{ml}$ anti ceramide antibody (clone MID 15B4, Alexis, Grünberg, Germany) in PBS containing $0.1 \%$ bovine serum albumin (BSA) at a dilution of 1:10. The samples were washed twice with PBS-BSA. The cells were stained for 30 minutes with polyclonal fluorescein isothiocyanate (FITC) conjugated goat anti-mouse IgG and IgM specific antibody (Pharmingen, Hamburg, Germany) diluted 1:50 in PBS-BSA. Unbound secondary antibody was removed by repeated washing with PBS-BSA. The samples were analyzed by flow cytometry with an excitation wavelength of $488 \mathrm{~nm}$ and an emission wavelength of $530 \mathrm{~nm}$. As a control, secondary antibody alone was used.

\section{Statistics}

Data are expressed as arithmetic means \pm SEM. As indicated in the figure legends, statistical analysis was made using ANOVA with Tukey's test as post-test and $t$ test as appropriate. $\mathrm{n}$ denotes the number of different erythrocyte specimens studied. Since different erythrocyte specimens used in distinct experiments are differently susceptible to triggers of eryptosis, the same erythrocyte specimens have been used for control and experimental conditions.

\section{Results}

The present study explored the effect of emodin on phospholipid scrambling of the cell membrane with phosphatidylserine translocation to the cell surface as well as on erythrocyte volume.

Phosphatidylserine exposing erythrocytes were identified utilizing annexin-V-binding, as determined by flow cytometry. Prior to measurements, the erythrocytes were incubated for 48 hours in Ringer solution without or with emodin $(10-75 \mu \mathrm{M})$. As shown in Fig. 1, a 48 hours exposure to emodin significantly increased the percentage of phosphatidylserine exposing erythrocytes at all emodin concentrations tested $(10-75 \mu \mathrm{M})$. As illustrated in Fig. $1 \mathrm{C}$, the effect of $75 \mu \mathrm{M}$ emodin reached statistical significance within 24 hours and the effect of $25 \mu \mathrm{M}$ emodin exposure reached statistical significance within 48 hours.

Erythrocyte volume was estimated from forward scatter which was determined utilizing flow cytometry. Prior to measurements, the erythrocytes were again incubated for 48 hours in Ringer solution without or with emodin $(10-75 \mu \mathrm{M})$. As illustrated in Fig. 2, emodin increased erythrocyte forward scatter, an effect reaching statistical significance at $50 \mu \mathrm{M}$ emodin concentration.

A further series of experiments explored whether emodin influences hemolysis. The percentage of hemolytic erythrocytes was determined utilizing hemoglobin concentration in 
Fig. 1. Effect of emodin on phosphatidylserine exposure. A. Original histogram of annexin-V-binding of erythrocytes following exposure for 48 hours to Ringer solution without (grey area) and with (black line) presence of $75 \mu \mathrm{M}$ emodin. B. Arithmetic means \pm SEM (n $=15$ ) of erythrocyte annexin-V-binding following incubation for 48 hours to Ringer solution without (white bar) or with (black bars) emodin $(10-75 \mu \mathrm{M})$. For comparison, the effect of the solvent DMSO is shown (grey bar). C. Time course of annexin-V-binding of erythrocytes following exposure to Ringer solution without (white bars) and with presence of $25 \mu \mathrm{M}$ emodin (grey bars) or $75 \mu \mathrm{M}$ emodin (black bars). ${ }^{*}(\mathrm{p}<0.05)$, $* *(\mathrm{p}<0.01)$ and ${ }^{* * *}(\mathrm{p}<0.001)$ indicates significant difference from the absence of emodin (ANOVA).

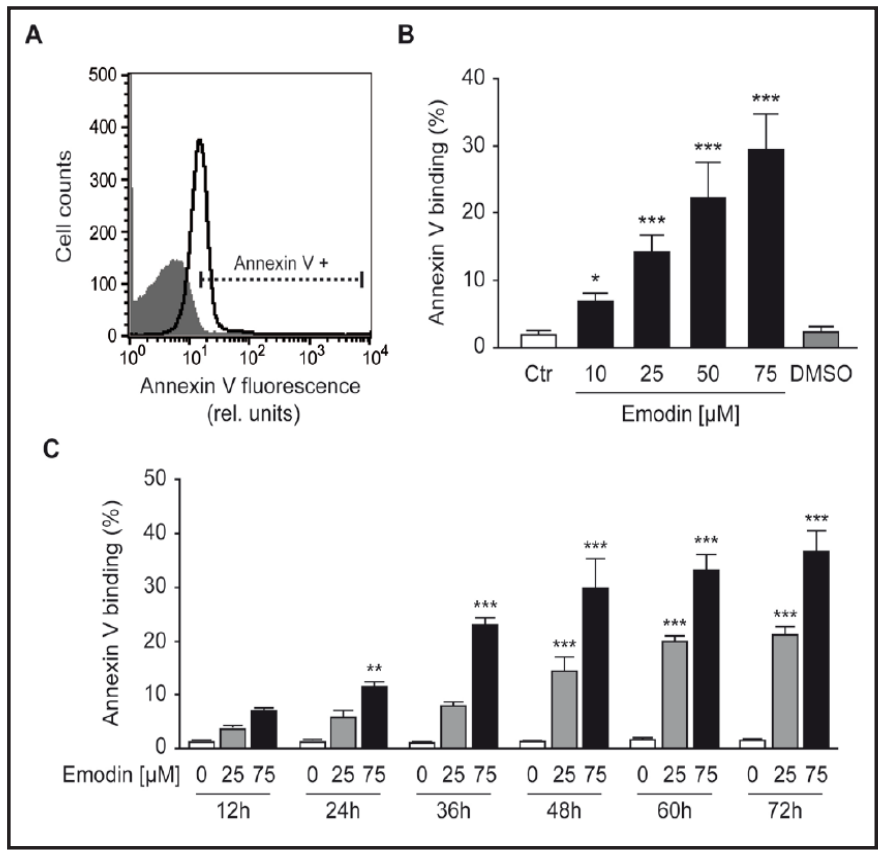

Fig. 2. Effect of emodin on A erythrocyte forward scatter. A. Original histogram of forward scatter of erythrocytes following exposure for 48 hours to Ringer solution without (grey area) and with (black line) presence of 75 $\mu \mathrm{M}$ emodin. B. Arithmetic means \pm SEM $(n=15)$ of the erythrocyte forward scatter (FSC) fol-

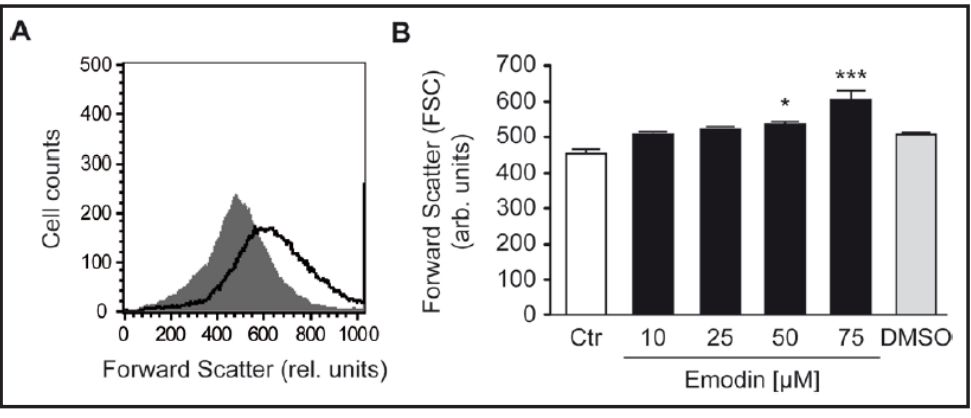
lowing incubation for 48 hours to Ringer solution without (white bar) or with (black bars) emodin (10 - 75 $\mu \mathrm{M})$. For comparison, the effect of the solvent DMSO is shown (grey bar). ${ }^{*}(\mathrm{p}<0.05),{ }^{* * *}(\mathrm{p}<0.001)$ indicates significant difference from the absence of emodin (ANOVA).

Fig. 3. Effect of emodin on erythrocyte hemolysis. Arithmetic means \pm SEM $(n=15)$ of the percentage hemolytic erythrocytes following incubation for 48 hours to Ringer solution without (white bar) or with (black bars) emodin $(10-75 \mu \mathrm{M})$. For comparison, the effect of the solvent DMSO is shown (grey bar). $* * *(\mathrm{p}<0.01)$ indicates significant difference from the absence of emodin (ANOVA).

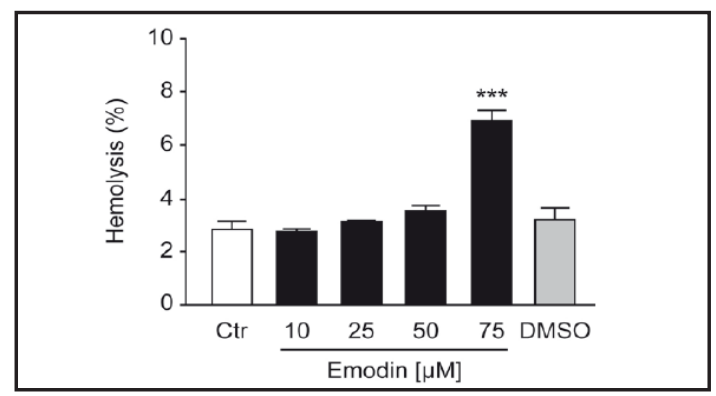

the supernatant. Prior to measurements, the erythrocytes were again incubated for 48 hours in Ringer solution without or with emodin $(10-75 \mu \mathrm{M})$. As illustrated in Fig. 3, emodin had little effect on hemolysis up to $50 \mu \mathrm{M}$ emodin, but significantly increased hemolysis at $75 \mu \mathrm{M}$ emodin.

Fluo3 fluorescence was taken as a measure of cytosolic $\mathrm{Ca}^{2+}$ activity $\left(\left[\mathrm{Ca}^{2+}\right]_{\mathrm{i}}\right)$. Prior to loading with the fluorescent dye, the erythrocytes were again incubated for 48 hours in Ringer solution without or with emodin $(10-75 \mu \mathrm{M})$. As illustrated in Fig. 4, emodin increased Fluo3 fluorescence at all emodin concentrations tested (10 - $75 \mu \mathrm{M})$. 
Fig. 4. Effect of emodin on cytosolic $\mathrm{Ca}^{2+}$ activity. A. Original histogram of Fluo3 fluorescence in erythrocytes following exposure for 48 hours to Ringer solution without (grey area) and with (black line) presence of $75 \mu \mathrm{M}$ emodin. B. Arithmetic means \pm SEM $(n=15)$ of Fluo3 fluorescence in erythrocytes following incubation for 48 hours to Ringer solution without (white bar) or

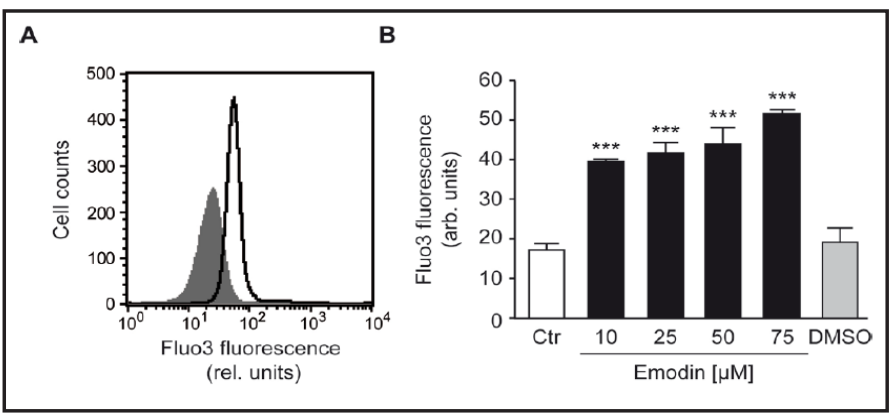
with (black bars) emodin (10 - $75 \mu \mathrm{M})$. For comparison, the effect of the solvent DMSO is shown (grey bar). ${ }^{* * *}(p<0.001)$ indicates significant difference from the absence of emodin (ANOVA).

Fig. 5. $\mathrm{Ca}^{2+}$ sensitivity of emodin-induced phosphatidylserine exposure. A,B. Original histograms of annexin-Vbinding of erythrocytes following exposure for 48 hours to Ringer solution without (grey areas) and with (black lines) emodin $(75 \mu \mathrm{M})$ in the presence (A) and absence (B) of extracellular $\mathrm{Ca}^{2+}$. C. Arithmetic means \pm SEM $(\mathrm{n}=$ 15) of annexin-V-binding of erythrocytes after a 48 hours treatment with Ringer solution without (white bars) or with emodin $(25 \mu \mathrm{M}$, grey bars, and $75 \mu \mathrm{M}$, black bars) in the presence (left bars, $+\mathrm{Ca}^{2+}$ ) and absence (right bars, $\left.-\mathrm{Ca}^{2+}\right)$ of $\mathrm{Ca}^{2+} . *(\mathrm{p}<0.05)$ and ${ }^{* * *}(\mathrm{p}<0.001)$ indicates significant difference from the absence of emodin (ANOVA), \#\#(p<0.01) and $\# \# \#(p<0.001)$ indicates significant difference from the presence of $\mathrm{Ca}^{2+}$ (ANOVA).

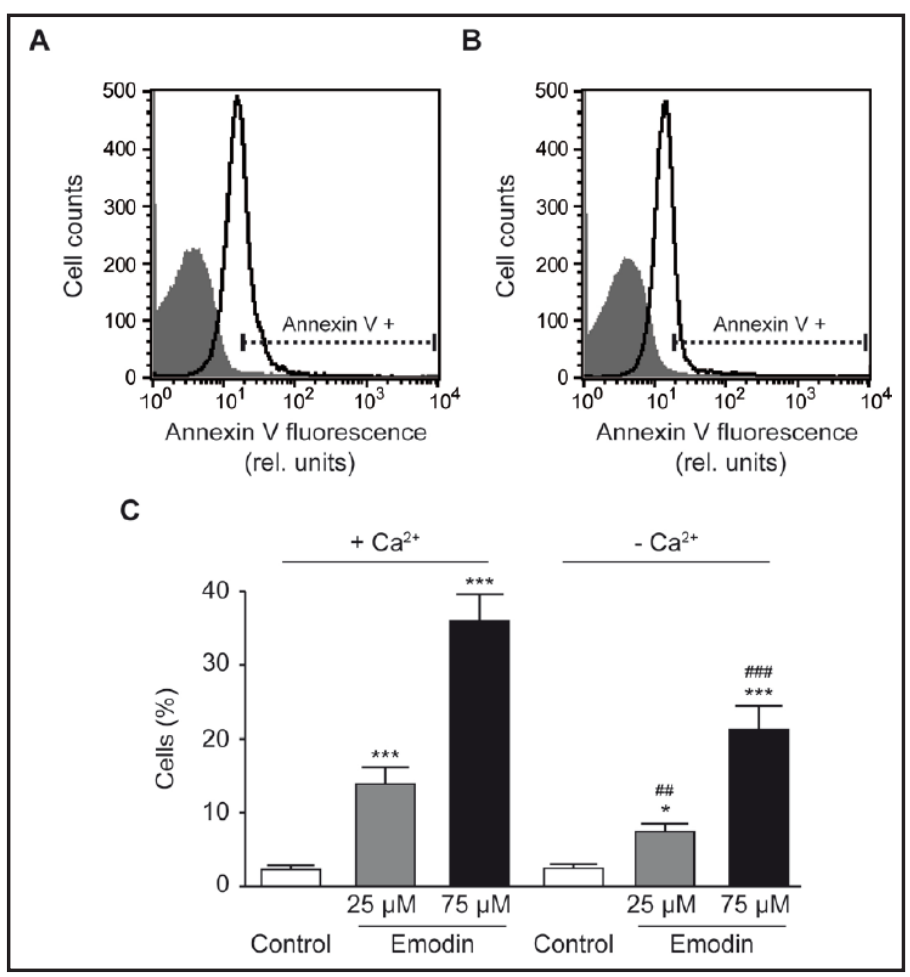

In order to test whether the emodin-induced translocation of phosphatidylserine or erythrocyte shrinkage required entry of extracellular $\mathrm{Ca}^{2+}$, erythrocytes were incubated for 48 hours in the absence or presence of $25 \mu \mathrm{M}$ or $75 \mu \mathrm{M}$ emodin in the presence or nominal absence of extracellular $\mathrm{Ca}^{2+}$. As illustrated in Fig. 5, removal of extracellular $\mathrm{Ca}^{2+}$ significantly blunted the effect of emodin on annexin-V-binding. However, even in the absence of extracellular $\mathrm{Ca}^{2+}$, emodin significantly increased the percentage of annexin-Vbinding erythrocytes (Fig. 5). Thus, emodin-induced cell membrane scrambling was in part, but not exclusively triggered by entry of extracellular $\mathrm{Ca}^{2+}$.

Erythrocyte cell membrane scrambling is further stimulated by oxidative stress [118]. Reactive oxygen species (ROS) was thus quantified utilizing $2^{\prime}, 7^{\prime}$-dichlorodihydrofluorescein diacetate (DCFDA). As illustrated in Fig. 6, emodin (75 $\mu \mathrm{M})$ significantly increased DCFDA fluorescence. Thus, emodin induced oxidative stress. In order to test, whether oxidative stress was required for the effect of emodin on phosphatidylserine translocation, emodin was applied in the absence and presence of antioxidant $\mathrm{N}$-acetylcysteine $(1 \mathrm{mM})$. As a result, the percentage of annexin-V-binding erythrocytes increased following exposure to $25 \mu \mathrm{M}$ or $75 \mu \mathrm{M}$ emodin for 48 hours to similar values in the absence (from $1.4 \pm 0.4 \%$ to $12.8 \pm 1.2$ $\%$ or $26.1 \pm 2.2 \%, \mathrm{n}=9$ each) and presence (from $2.1 \pm 0.1 \%$ to $13.1 \pm 1.6 \%$ or $24.3 \pm 3.8$ 


\section{Cellular Physiology Cell Physiol Biochem 2016;40:91-103

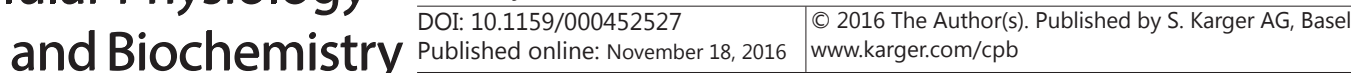

Fig. 6. Effect of emodin on ROS formation. A. Original histogram of DCFDA fluorescence in erythrocytes following exposure for 48 hours to Ringer solution without (grey area) and with (black line) presence of emodin $(75 \mu \mathrm{M})$. B. Arithmetic means \pm SEM ( $n=15)$ of the DCFDA fluorescence (arbitrary units) in erythrocytes exposed for 48 hours to Ringer solution without (white bar) or with (black bar) emodin $(75 \mu \mathrm{M})$. $* * *(\mathrm{p}<0.001)$ indicates significant difference from the absence of emodin (ANOVA).

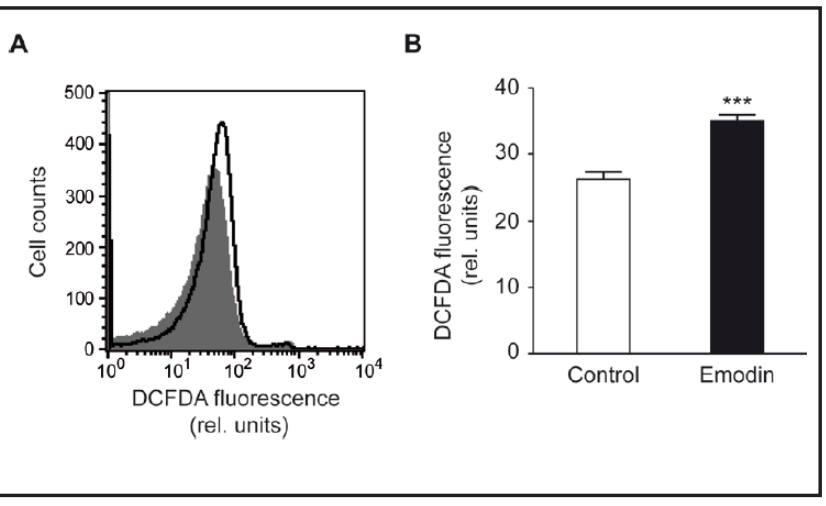

Fig. 7. Effect of emodin on ceramide abundance at the erythrocyte surface. A. Original histogram of ceramide abundance in erythrocytes following exposure for 48 hours to Ringer solution without (grey area) and with (black line) presence of emodin (75 $\mu \mathrm{M})$. B. Arithmetic means \pm SEM $(n=15)$ of the ceramide abundance (arbitrary units) in erythrocytes exposed for 48 hours to Ringer solution without (white bar) or with (black bar) emodin $(75 \mu \mathrm{M}) .{ }^{* * *}(\mathrm{p}<0.001)$ indicates significant difference from the $a b$ sence of emodin (ANOVA).

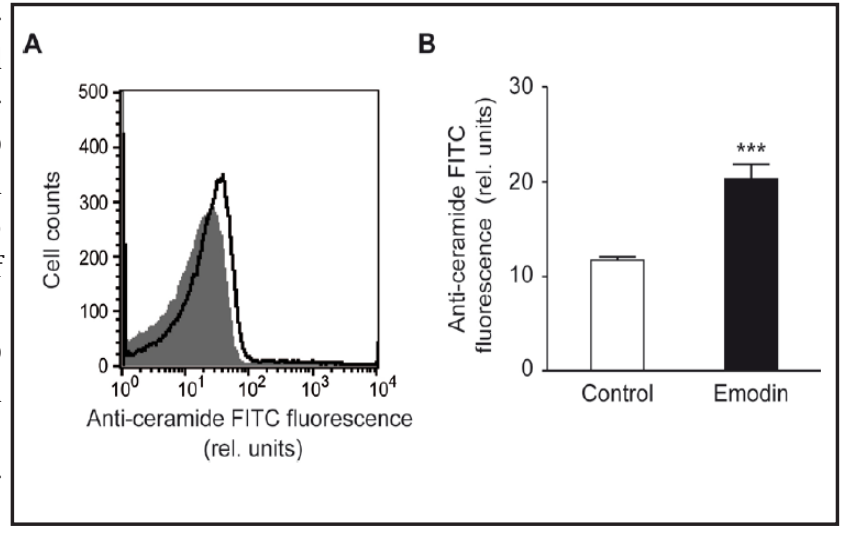

$\%, \mathrm{n}=9$ each) of $\mathrm{N}$-acetylcysteine. The effect of emodin thus apparently does not require oxidative stress.

A further stimulator of eryptosis is ceramide. Ceramide abundance at the erythrocyte surface was thus quantified utilizing specific antibodies. As illustrated in Fig. 7, emodin (75 $\mu \mathrm{M}$ ) significantly increased the ceramide abundance at the erythrocyte surface.

\section{Discussion}

The present observations reveal that emodin induces cell membrane scrambling with phosphatidylserine translocation to the erythrocyte surface. The emodin concentration required for the effect is well in the range of plasma concentrations observed in vivo [119]. Cell membrane scrambling is the most important hallmark of eryptosis, the suicidal erythrocyte death [71]. However, emodin did not induce cell shrinkage, the other hallmark of eryptosis [71]. Instead, higher concentrations of emodin triggered significant cell swelling.

The stimulating effect of emodin on cell membrane scrambling was paralleled by an increase of cytosolic $\mathrm{Ca}^{2+}$ activity $\left(\left[\mathrm{Ca}^{2+}\right]_{\mathrm{i}}\right)$. Moreover, the emodin-induced cell membrane scrambling was in part dependent on $\mathrm{Ca}^{2+}$ entry from the extracellular space, as removal of extracellular $\mathrm{Ca}^{2+}$ significantly blunted emodin induced cell membrane scrambling. However, even in the nominal absence of extracellular $\mathrm{Ca}^{2+}$, emodin significantly induced cell membrane scrambling, an observation pointing to involvement of additional mechanisms. Emodin triggered oxidative stress, a well known stimulator of eryptosis [71]. The antioxidant $\mathrm{N}$-acetylcysteine did, however, not significantly blunt the effect of emodin on annexin-V-binding. Emodin could thus apparently trigger erythrocyte cell membrane scrambling even in the absence of oxidative stress. Emodin further significantly enhanced the abundance of ceramide, which could sensitize cells for the scrambling effect of $\mathrm{Ca}^{2+}[71]$.

Despite the increase of $\left[\mathrm{Ca}^{2+}\right]_{i}$, emodin did not lead to cell shrinkage. The increase of $\left[\mathrm{Ca}^{2+}\right]_{\mathrm{i}}$ were expected to activate $\mathrm{Ca}^{2+}$ sensitive $\mathrm{K}^{+}$channels leading to $\mathrm{K}^{+}$exit, cell membrane 


\section{Cellular Physiology Cell Physiol Biochem 2016;40:91-103 \begin{tabular}{l|l|l} 
and Biochemistry Published online: November 18, 2016 & $\begin{array}{l}\text { C } 2016 \text { The Author(s). Published by S. Karger AG, Basel } \\
\text { www.karger.com/cpb }\end{array}$
\end{tabular} \\ Mischitelli et al.: Emodin-Induced Eryptosis}

hyperpolarization, $\mathrm{Cl}^{-}$exit and thus cellular loss of $\mathrm{KCl}$ with water. The underlying mechanism of emodin-induced erythrocyte swelling remained elusive. Potential mechanisms include impairment of $\mathrm{Na}^{+} / \mathrm{K}^{+}$ATPase activity which would decrease the cellular $\mathrm{K}^{+}$content and thus interfere with $\mathrm{Ca}^{2+}$ induced hyperpolarization.

High concentrations of emodin triggered hemolysis thus leading to release of hemoglobin, which passes the renal glomerular filter, precipitates in the acidic lumen of renal tubules, occludes nephrons and thus may lead to renal failure [120].

Phosphatidylserine exposing erythrocytes are rapidly cleared from circulating blood and stimulation of eryptosis may lead to anemia as soon as the loss of erythrocytes surpasses the formation of new erythrocytes by erythropoiesis [71]. Along those lines, eryptosis may contribute to anemia in several clinical conditions, such as iron deficiency [71], dehydration [121], hyperphosphatemia [122], chronic kidney disease (CKD) [123-126], hemolyticuremic syndrome [127], diabetes [128], hepatic failure [129], malignancy [71], sepsis [130], sickle-cell disease [71], beta-thalassemia [71], Hb-C and G6PD-deficiency [71], as well as Wilsons disease [131].

Phosphatidylserine exposing erythrocytes may further interfere with microcirculation $[73,132-136]$, as they adhere to the vascular wall [137], stimulate blood clotting and trigger thrombosis $[132,138,139]$.

\section{Conclusion}

Emodin triggers cell membrane scrambling, an effect paralleled by increase of cytosolic $\mathrm{Ca}^{2+}$ activity and partially dependent on $\mathrm{Ca}^{2+}$ entry, and in addition paralleled by oxidative stress and increase of ceramide abundance at the erythrocyte surface.

\section{Acknowledgements}

The authors acknowledge the meticulous preparation of the manuscript by Tanja Loch and Lejla Subasic. The study was supported by the Deutsche Forschungsgemeinschaft and Open Access Publishing Fund of Tuebingen University.

\section{Disclosure Statement}

None.

\section{References}

1 Shrimali D, Shanmugam MK, Kumar AP, Zhang J, Tan BK, Ahn KS, Sethi G: Targeted abrogation of diverse signal transduction cascades by emodin for the treatment of inflammatory disorders and cancer. Cancer Lett 2013;341:139-149.

2 Dong X, Fu J, Yin X, Cao S, Li X, Lin L, Huyiligeqi, Ni J: Emodin: A Review of its Pharmacology, Toxicity and Pharmacokinetics. Phytother Res 2016;10.1002/ptr.5631

3 Srinivas G, Babykutty S, Sathiadevan PP, Srinivas P: Molecular mechanism of emodin action: transition from laxative ingredient to an antitumor agent. Med Res Rev 2007;27:591-608.

4 Li L, Song X, Yin Z, Jia R, Li Z, Zhou X, Zou Y, Li L, Yin L, Yue G, Ye G, Lv C, Shi W, Fu Y: The antibacterial activity and action mechanism of emodin from Polygonum cuspidatum against Haemophilus parasuis in vitro. Microbiol Res 2016;186-187:139-145.

5 Chen Q, Tian S, Zhu J, Li KT, Yu TH, Yu LH, Bai DQ: Exploring a Novel Target Treatment on Breast Cancer: Aloe-emodin Mediated Photodynamic Therapy Induced Cell Apoptosis and Inhibited Cell Metastasis. Anticancer Agents Med Chem 2016;16:763-770.

6 Chen R, Zhang J, Hu Y, Wang S, Chen M, Wang Y: Potential antineoplastic effects of Aloe-emodin: a comprehensive review. Am J Chin Med 2014;42:275-288.

7 Chen Y, Li J, Hu J, Zheng J, Zheng Z, Liu T, Lin Z, Lin M: Emodin enhances ATRA-induced differentiation and induces apoptosis in acute myeloid leukemia cells. Int J Oncol 2014;45:2076-2084. 


\section{Cellular Physiology Cell Physiol Biochem 2016;40:91-103 \begin{tabular}{l|l|l} 
and Biochemistry $\begin{array}{l}\text { DOI: 10.1159/000452527 } \\
\text { Published online: November 18, } 2016\end{array}$ & $\begin{array}{l}\text { C } 2016 \text { The Author(s). Published by S. Karger AG, Basel } \\
\text { www.karger.com/cpb }\end{array}$
\end{tabular} \\ Mischitelli et al.: Emodin-Induced Eryptosis}

8 Chen YY, Chiang SY, Lin JG, Ma YS, Liao CL, Weng SW, Lai TY, Chung JG: Emodin, aloe-emodin and rhein inhibit migration and invasion in human tongue cancer SCC-4 cells through the inhibition of gene expression of matrix metalloproteinase-9. Int J Oncol 2010;36:1113-1120.

9 Chen YY, Chiang SY, Lin JG, Yang JS, Ma YS, Liao CL, Lai TY, Tang NY, Chung JG: Emodin, aloe-emodin and rhein induced DNA damage and inhibited DNA repair gene expression in SCC-4 human tongue cancer cells. Anticancer Res 2010;30:945-951.

10 Chihara T, Shimpo K, Beppu H, Yamamoto N, Kaneko T, Wakamatsu K, Sonoda S: Effects of Aloe-emodin and Emodin on Proliferation of the MKN45 Human Gastric Cancer Cell Line. Asian Pac J Cancer Prev 2015;16:3887-3891.

11 Chun-Guang W, Jun-Qing Y, Bei-Zhong L, Dan-Ting J, Chong W, Liang Z, Dan Z, Yan W: Anti-tumor activity of emodin against human chronic myelocytic leukemia K562 cell lines in vitro and in vivo. Eur J Pharmacol 2010;627:33-41.

12 Deng G, Ju X, Meng Q, Yu ZJ, Ma LB: Emodin inhibits the proliferation of PC3 prostate cancer cells in vitro via the Notch signaling pathway. Mol Med Rep 2015;12:4427-4433.

13 Guo J, Li W, Shi H, Xie X, Li L, Tang H, Wu M, Kong Y, Yang L, Gao J, Liu P, Wei W, Xie X: Synergistic effects of curcumin with emodin against the proliferation and invasion of breast cancer cells through upregulation of miR-34a. Mol Cell Biochem 2013;382:103-111.

14 Haris K, Ismail S, Idris Z, Abdullah JM, Yusoff AA: Expression profile of genes modulated by Aloe emodin in human U87 glioblastoma cells. Asian Pac J Cancer Prev 2014;15:4499-4505.

15 Hsu CM, Hsu YA, Tsai Y, Shieh FK, Huang SH, Wan L, Tsai FJ: Emodin inhibits the growth of hepatoma cells: finding the common anti-cancer pathway using Huh7, Hep3B, and HepG2 cells. Biochem Biophys Res Commun 2010;392:473-478.

16 Huang FJ, Hsuuw YD, Chan WH: Characterization of apoptosis induced by emodin and related regulatory mechanisms in human neuroblastoma cells. Int J Mol Sci 2013;14:20139-20156.

17 Jelassi B, Anchelin M, Chamouton J, Cayuela ML, Clarysse L, Li J, Gore J, Jiang LH, Roger S: Anthraquinone emodin inhibits human cancer cell invasiveness by antagonizing P2X7 receptors. Carcinogenesis 2013;34:1487-1496.

18 Jia X, Yu F, Wang J, Iwanowycz S, Saaoud F, Wang Y, Hu J, Wang Q, Fan D: Emodin suppresses pulmonary metastasis of breast cancer accompanied with decreased macrophage recruitment and M2 polarization in the lungs. Breast Cancer Res Treat 2014;148:291-302.

19 Kim J, Lee JS, Jung J, Lim I, Lee JY, Park MJ: Emodin suppresses maintenance of stemness by augmenting proteosomal degradation of epidermal growth factor receptor/epidermal growth factor receptor variant III in glioma stem cells. Stem Cells Dev 2015;24:284-295.

20 Ku HJ, Kwon OS, Kang BS, Lee DS, Lee HS, Park JW: IDH2 knockdown sensitizes tumor cells to emodin cytotoxicity in vitro and in vivo. Free Radic Res 2016;10.1080/10715762.2016.11787391-9.

21 Lai JM, Chang JT, Wen CL, Hsu SL: Emodin induces a reactive oxygen species-dependent and ATM-p53-Bax mediated cytotoxicity in lung cancer cells. Eur J Pharmacol 2009;623:1-9.

22 Li WY, Chan RY, Yu PH, Chan SW: Emodin induces cytotoxic effect in human breast carcinoma MCF-7 cell through modulating the expression of apoptosis-related genes. Pharm Biol 2013;51:1175-1181.

23 Liu B, Yuan B, Zhang L, Mu W, Wang C: ROS/p38/p53/Puma signaling pathway is involved in emodininduced apoptosis of human colorectal cancer cells. Int J Clin Exp Med 2015;8:15413-15422.

24 Liu H, Gao M, Xu H, Guan X, Lv L, Deng S, Zhang C, Tian Y: A Promising Emodin-Loaded Poly (Lactic-CoGlycolic Acid)-d-alpha-Tocopheryl Polyethylene Glycol 1000 Succinate Nanoparticles for Liver Cancer Therapy. Pharm Res 2016;33:217-236.

25 Ma J, Yang J, Wang C, Zhang N, Dong Y, Wang C, Wang Y, Lin X: Emodin augments cisplatin cytotoxicity in platinum-resistant ovarian cancer cells via ROS-dependent MRP1 downregulation. Biomed Res Int 2014;2014:107671.

26 Ma L, Li W: Emodin inhibits LOVO colorectal cancer cell proliferation via the regulation of the Bcl-2/Bax ratio and cytochrome c. Exp Ther Med 2014;8:1225-1228.

27 Ma YS, Weng SW, Lin MW, Lu CC, Chiang JH, Yang JS, Lai KC, Lin JP, Tang NY, Lin JG, Chung JG: Antitumor effects of emodin on LS1034 human colon cancer cells in vitro and in vivo: roles of apoptotic cell death and LS1034 tumor xenografts model. Food Chem Toxicol 2012;50:1271-1278.

28 Sui JQ Xie KP, Zou W, Xie MJ: Emodin inhibits breast cancer cell proliferation through the ERalpha-MAPK/ Akt-cyclin D1/Bcl-2 signaling pathway. Asian Pac J Cancer Prev 2014;15:6247-6251. 


\section{Cellular Physiology Cell Physiol Biochem 2016;40:91-103

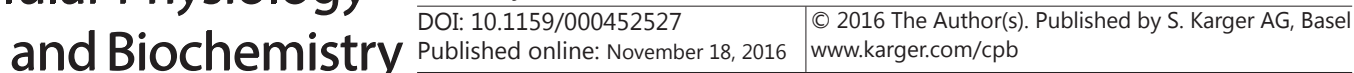 \\ Mischitelli et al.: Emodin-Induced Eryptosis}

29 Tabolacci C, Cordella M, Turcano L, Rossi S, Lentini A, Mariotti S, Nisini R, Sette G, Eramo A, Piredda L, De Maria R, Facchiano F, Beninati S: Aloe-emodin exerts a potent anticancer and immunomodulatory activity on BRAF-mutated human melanoma cells. Eur J Pharmacol 2015;762:283-292.

30 Wang Y, Yu H, Zhang J, Ge X, Gao J, Zhang Y, Lou G: Anti-tumor effect of emodin on gynecological cancer cells. Cell Oncol (Dordr) 2015;38:353-363.

31 Wei WT, Lin SZ, Liu DL, Wang ZH: The distinct mechanisms of the antitumor activity of emodin in different types of cancer (Review). Oncol Rep 2013;30:2555-2562.

32 Xie MJ, Ma YH, Miao L, Wang Y, Wang HZ, Xing YY, Xi T, Lu YY: Emodin-provoked oxidative stress induces apoptosis in human colon cancer HCT116 cells through a p53-mitochondrial apoptotic pathway. Asian Pac J Cancer Prev 2014;15:5201-5205.

33 Xing JY, Song GP, Deng JP, Jiang LZ, Xiong P, Yang BJ, Liu SS: Antitumor Effects and Mechanism of Novel Emodin Rhamnoside Derivatives against Human Cancer Cells In Vitro. PLoS One 2015;10:e0144781.

34 Xue H, Chen Y, Cai X, Zhao L, He A, Guo K, Zheng X: The combined effect of survivin-targeted shRNA and emodin on the proliferation and invasion of ovarian cancer cells. Anticancer Drugs 2013;24:937-944.

35 Yan YY, Fu LW, Zhang W, Ma HS, Ma CG, Liang YJ, Liu BY, Yu JZ, Wu QZ, Dong YM: Emodin azide methyl anthraquinone derivative induced G0/ G1 arrest in HER2/neu-overexpressing MDA-MB-453 breast cancer cells. J BUON 2014;19:650-655.

36 Yang L, Tan J, Wang BC, Zhu LC: Synthesis, characterization, and anti-cancer activity of emodin-Mn(II) metal complex. Chin J Nat Med 2014;12:937-942.

37 Yang X, Zhao W, Hu X, Hao X, Hong F, Wang J, Xiang L, Zhu Y, Yuan Y, Ho RJ, Wang W, Shao J: Synthesis, Characterization, and Anticancer Activity of Novel Lipophilic Emodin Cationic Derivatives. Chem Biol Drug Des 2015;86:1451-1457.

38 Ying J, Xu H, Wu D, Wu X: Emodin induces apoptosis of human osteosarcoma cells via mitochondria- and endoplasmic reticulum stress-related pathways. Int J Clin Exp Pathol 2015;8:12837-12844.

39 Zhang H, Chen L, Bu HQ Yu QJ, Jiang DD, Pan FP, Wang Y, Liu DL, Lin SZ: Effects of emodin on the demethylation of tumor-suppressor genes in pancreatic cancer PANC-1 cells. Oncol Rep 2015;33:30153023.

40 Zhang X, Chen Y, Zhang T, Zhang Y: Inhibitory effect of emodin on human hepatoma cell line SMMC-7721 and its mechanism. Afr Health Sci 2015;15:97-100.

41 Zu C, Zhang M, Xue H, Cai X, Zhao L, He A, Qin G, Yang C, Zheng X: Emodin induces apoptosis of human breast cancer cells by modulating the expression of apoptosis-related genes. Oncol Lett 2015;10:29192924.

42 Chen H, Wei W, Guo Y, Liu A, Tong H, Wang Z, Tan W, Liu J, Lin S: Enhanced effect of gemcitabine by emodin against pancreatic cancer in vivo via cytochrome C-regulated apoptosis. Oncol Rep 2011;25:1253-1261.

43 Chen YC, Shen SC, Lee WR, Hsu FL, Lin HY, Ko CH, Tseng SW: Emodin induces apoptosis in human promyeloleukemic HL-60 cells accompanied by activation of caspase 3 cascade but independent of reactive oxygen species production. Biochem Pharmacol 2002;64:1713-1724.

44 Huang Z, Chen G, Shi P: Emodin-induced apoptosis in human breast cancer BCap-37 cells through the mitochondrial signaling pathway. Arch Pharm Res 2008;31:742-748.

45 Ismail S, Haris K, Abdul Ghani AR, Abdullah JM, Johan MF, Mohamed Yusoff AA: Enhanced induction of cell cycle arrest and apoptosis via the mitochondrial membrane potential disruption in human U87 malignant glioma cells by aloe emodin. J Asian Nat Prod Res 2013;15:1003-1012.

46 Jing X, Ueki N, Cheng J, Imanishi H, Hada T: Induction of apoptosis in hepatocellular carcinoma cell lines by emodin. Jpn J Cancer Res 2002;93:874-882.

47 Lee HZ: Protein kinase C involvement in aloe-emodin- and emodin-induced apoptosis in lung carcinoma cell. Br J Pharmacol 2001;134:1093-1103.

48 Li WY, Ng YF, Zhang H, Guo ZD, Guo DJ, Kwan YW, Leung GP, Lee SM, Yu PH, Chan SW: Emodin elicits cytotoxicity in human lung adenocarcinoma A549 cells through inducing apoptosis. Inflammopharmacology 2014;22:127-134.

49 Lin SY, Lai WW, Ho CC, Yu FS, Chen GW, Yang JS, Liu KC, Lin ML, Wu PP, Fan MJ, Chung JG: Emodin induces apoptosis of human tongue squamous cancer SCC-4 cells through reactive oxygen species and mitochondria-dependent pathways. Anticancer Res 2009;29:327-335.

50 Lin SZ, Wei WT, Chen H, Chen KJ, Tong HF, Wang ZH, Ni ZL, Liu HB, Guo HC, Liu DL: Antitumor activity of emodin against pancreatic cancer depends on its dual role: promotion of apoptosis and suppression of angiogenesis. PLoS One 2012; 7:e42146. 


\section{Cellular Physiology Cell Physiol Biochem 2016;40:91-103 \begin{tabular}{l|l|l} 
and BOI: 10.1159/000452527 & $\begin{array}{l}\text { C } 2016 \text { The Author(s). Published by S. Karger AG, Basel } \\
\text { www.karger.com/cpb }\end{array}$
\end{tabular} \\ Mischitelli et al.: Emodin-Induced Eryptosis}

51 Liu DL, Bu H, Li H, Chen H, Guo HC, Wang ZH, Tong HF, Ni ZL, Liu HB, Lin SZ: Emodin reverses gemcitabine resistance in pancreatic cancer cells via the mitochondrial apoptosis pathway in vitro. Int J Oncol 2012;40:1049-1057.

52 Liu JX, Zhang JH, Li HH, Lai FJ, Chen KJ, Chen H, Luo J, Guo HC, Wang ZH, Lin SZ: Emodin induces Panc-1 cell apoptosis via declining the mitochondrial membrane potential. Oncol Rep 2012;28:1991-1996.

53 Narender T, Sukanya P, Sharma K, Bathula SR: Preparation of novel antiproliferative emodin derivatives and studies on their cell cycle arrest, caspase dependent apoptosis and DNA binding interaction. Phytomedicine 2013;20:890-896.

54 Shieh DE, Chen YY, Yen MH, Chiang LC, Lin CC: Emodin-induced apoptosis through p53-dependent pathway in human hepatoma cells. Life Sci 2004;74:2279-2290.

55 Singh KB, Trigun SK: Apoptosis of Dalton's lymphoma due to in vivo treatment with emodin is associated with modulations of hydrogen peroxide metabolizing antioxidant enzymes. Cell Biochem Biophys 2013;67:439-449.

56 Srinivas G, Anto RJ, Srinivas P, Vidhyalakshmi S, Senan VP, Karunagaran D: Emodin induces apoptosis of human cervical cancer cells through poly(ADP-ribose) polymerase cleavage and activation of caspase-9. Eur J Pharmacol 2003;473:117-125.

57 Su YT, Chang HL, Shyue SK, Hsu SL: Emodin induces apoptosis in human lung adenocarcinoma cells through a reactive oxygen species-dependent mitochondrial signaling pathway. Biochem Pharmacol 2005;70:229-241.

58 Subramaniam A, Loo SY, Rajendran P, Manu KA, Perumal E, Li F, Shanmugam MK, Siveen KS, Park JI, Ahn KS, Hui KM, Kumar AP, Sethi G: An anthraquinone derivative, emodin sensitizes hepatocellular carcinoma cells to TRAIL induced apoptosis through the induction of death receptors and downregulation of cell survival proteins. Apoptosis 2013;18:1175-1187.

59 Subramaniam A, Shanmugam MK, Ong TH, Li F, Perumal E, Chen L, Vali S, Abbasi T, Kapoor S, Ahn KS, Kumar AP, Hui KM, Sethi G: Emodin inhibits growth and induces apoptosis in an orthotopic hepatocellular carcinoma model by blocking activation of STAT3. Br J Pharmacol 2013;170:807-821.

60 Sun ZH, Bu P: Downregulation of phosphatase of regenerating liver-3 is involved in the inhibition of proliferation and apoptosis induced by emodin in the SGC-7901 human gastric carcinoma cell line. Exp Ther Med 2012;3:1077-1081.

61 Wang QJ, Cai XB, Liu MH, Hu H, Tan XJ, Jing XB: Apoptosis induced by emodin is associated with alterations of intracellular acidification and reactive oxygen species in EC-109 cells. Biochem Cell Biol 2010;88:767774.

62 Wei WT, Chen H, Ni ZL, Liu HB, Tong HF, Fan L, Liu A, Qiu MX, Liu DL, Guo HC, Wang ZH, Lin SZ: Antitumor and apoptosis-promoting properties of emodin, an anthraquinone derivative from Rheum officinale Baill, against pancreatic cancer in mice via inhibition of Akt activation. Int J Oncol 2011;39:1381-1390.

63 Yan Y, Su X, Liang Y, Zhang J, Shi C, Lu Y, Gu L, Fu L: Emodin azide methyl anthraquinone derivative triggers mitochondrial-dependent cell apoptosis involving in caspase-8-mediated Bid cleavage. Mol Cancer Ther 2008;7:1688-1697.

64 Yaoxian W, Hui Y, Yunyan Z, Yanqin L, Xin G, Xiaoke W: Emodin induces apoptosis of human cervical cancer hela cells via intrinsic mitochondrial and extrinsic death receptor pathway. Cancer Cell Int 2013;13:71.

65 Yu CX, Zhang XQ, Kang LD, Zhang PJ, Chen WW, Liu WW, Liu QW, Zhang JY: Emodin induces apoptosis in human prostate cancer cell LNCaP. Asian J Androl 2008;10:625-634.

66 Yu JQ, Bao W, Lei JC: Emodin regulates apoptotic pathway in human liver cancer cells. Phytother Res 2013;27:251-257.

67 Liu A, Chen H, Tong H, Ye S, Qiu M, Wang Z, Tan W, Liu J, Lin S: Emodin potentiates the antitumor effects of gemcitabine in pancreatic cancer cells via inhibition of nuclear factor-kappaB. Mol Med Rep 2011;4:221227.

68 Zhang W, Chen H, Liu DL, Li H, Luo J, Zhang JH, Li Y, Chen KJ, Tong HF, Lin SZ: Emodin sensitizes the gemcitabine-resistant cell line Bxpc-3/Gem to gemcitabine via downregulation of NF-kappaB and its regulated targets. Int J Oncol 2013;42:1189-1196.

69 Pooja T, Karunagaran D: Emodin suppresses Wnt signaling in human colorectal cancer cells SW480 and SW620. Eur J Pharmacol 2014;742:55-64.

70 Wang W, Sun Y, Li X, Li H, Chen Y, Tian Y, Yi J, Wang J: Emodin potentiates the anticancer effect of cisplatin on gallbladder cancer cells through the generation of reactive oxygen species and the inhibition of survivin expression. Oncol Rep 2011;26:1143-1148. 


\section{Cellular Physiology Cell Physiol Biochem 2016;40:91-103 \begin{tabular}{l|l|l} 
and BOI: 10.1159/000452527 & $\begin{array}{l}\text { @ } 2016 \text { The Author(s). Published by S. Karger AG, Basel } \\
\text { www.karger.com/cpb }\end{array}$
\end{tabular} \\ Mischitelli et al.: Emodin-Induced Eryptosis}

71 Lang E, Lang F: Mechanisms and pathophysiological significance of eryptosis, the suicidal erythrocyte death. Semin Cell Dev Biol 2015;39:35-42.

72 Lang PA, Kaiser S, Myssina S, Wieder T, Lang F, Huber SM: Role of Ca2+-activated K+ channels in human erythrocyte apoptosis. Am J Physiol Cell Physiol 2003;285:C1553-C1560.

73 Abed M, Towhid ST, Mia S, Pakladok T, Alesutan I, Borst O, Gawaz M, Gulbins E, Lang F: Sphingomyelinaseinduced adhesion of eryptotic erythrocytes to endothelial cells. Am J Physiol Cell Physiol 2012;303:C991999.

74 Lau IP, Chen H, Wang J, Ong HC, Leung KC, Ho HP, Kong SK: In vitro effect of CTAB- and PEG-coated gold nanorods on the induction of eryptosis/erythroptosis in human erythrocytes. Nanotoxicology 2012;6:847856.

75 Maellaro E, Leoncini S, Moretti D, Del Bello B, Tanganelli I, De Felice C, Ciccoli L: Erythrocyte caspase-3 activation and oxidative imbalance in erythrocytes and in plasma of type 2 diabetic patients. Acta Diabetol 2013;50:489-495.

76 Alzoubi K, Calabròa S, Bissinger R, Abed M, Faggio C, Lang F: Stimulation of Suicidal Erythrocyte Death by Artesunate. Cell Physiol Biochem 2014;34:2232-2244.

77 Alzoubi K, Egler J, Abed M, Lang F: Enhanced Eryptosis Following Auranofin Exposure. Cell Physiol Biochem 2015;37:1018-1028.

78 Arnold M, Bissinger R, Lang F: Mitoxantrone-induced suicidal erythrocyte death. Cell Physiol Biochem 2014;34:1756-1767.

79 Arnold M, Lang E, Modicano P, Bissinger R, Faggio C, Abed M, Lang F: Effect of nitazoxanide on erythrocytes. Basic Clin Pharmacol Toxicol 2014;114:421-426.

80 Bissinger R, Barking S, Alzoubi K, Liu G, Liu G, Lang F: Stimulation of Suicidal Erythrocyte Death by the Antimalarial Drug Mefloquine. Cell Physiol Biochem 2015;36:1395-1405.

81 Bissinger R, Bouguerra G, Stockinger K, Abbes S, Lang F: Triggering of Suicidal Erythrocyte Death by Topotecan. Cell Physiol Biochem 2015;37:1607-1618.

82 Bissinger R, Fischer S, Jilani K, Lang F: Stimulation of Erythrocyte Death by Phloretin. Cell Physiol Biochem 2014;34:2256-2265.

83 Bissinger R, Lupescu A, Zelenak C, Jilani K, Lang F: Stimulation of eryptosis by cryptotanshinone. Cell Physiol Biochem 2014;34:432-442.

84 Bouguerra G, Aljanadi O, Bissinger R, Abbes S, Lang F: Embelin-Induced Phosphatidylserine Translocation in the Erythrocyte Cell Membrane. Cell Physiol Biochem 2015;37:1629-1640.

85 Bouguerra G, Bissinger R, Abbes S, Lang F: Stimulation of Eryptosis by Narasin. Cell Physiol Biochem 2015;37:1807-1816

86 Bouguerra G, Bissinger R, Abbes S, Lang F: Zopolrestat Induced Suicidal Death of Human Erythrocytes. Cell Physiol Biochem 2015;37:1537-1546.

87 Briglia M, Fazio A, Faggio C, Laufer S, Alzoubi K, Lang F: Triggering of Suicidal Erythrocyte Death by Ruxolitinib. Cell Physiol Biochem 2015;37:768-778.

88 Briglia M, Fazio A, Signoretto E, Faggio C, Lang F: Edelfosine Induced Suicidal Death of Human Erythrocytes. Cell Physiol Biochem 2015;37:2221-2230.

89 Calabro S, Alzoubi K, Faggio C, Laufer S, Lang F: Triggering of Suicidal Erythrocyte Death Following Boswellic Acid Exposure. Cell Physiol Biochem 2015;37:131-142.

90 Egler J, Lang F: Licochalcone A Induced Suicidal Death of Human Erythrocytes. Cell Physiol Biochem 2015;37:2060-2070.

91 Faggio C, Alzoubi K, Calabro S, Lang F: Stimulation of suicidal erythrocyte death by PRIMA-1. Cell Physiol Biochem 2015;35:529-540.

92 Fazio A, Briglia M, Faggio C, Alzoubi K, Lang F: Stimulation of Suicidal Erythrocyte Death by Garcinol. Cell Physiol Biochem 2015;37:805-815.

93 Jacobi J, Lang E, Bissinger R, Frauenfeld L, Modicano P, Faggio C, Abed M, Lang F: Stimulation of erythrocyte cell membrane scrambling by mitotane. Cell Physiol Biochem 2014;33:1516-1526.

94 Lang E, Jilani K, Bissinger R, Rexhepaj R, Zelenak C, Lupescu A, Lang F, Qadri SM: Vitamin D-Rich Diet in Mice Modulates Erythrocyte Survival. Kidney Blood Press Res 2015;40:403-412.

95 Lang E, Zelenak C, Eberhard M, Bissinger R, Rotte A, Ghashghaeinia M, Lupescu A, Lang F, Qadri SM: Impact of Cyclin-Dependent Kinase CDK4 Inhibition on Eryptosis. Cell Physiol Biochem 2015;37:1178-1186. 


\section{Cellular Physiology Cell Physiol Biochem 2016;40:91-103 \begin{tabular}{l|l|l} 
and Biochemistry & $\begin{array}{l}\text { DOI: 10.1159/000452527 } \\
\text { Published online: November 18, } 2016\end{array}$ & $\begin{array}{l}\text { (c) } 2016 \text { The Author(s). Published by S. Karger AG, Basel } \\
\text { www.karger.com/cpb }\end{array}$
\end{tabular} \\ Mischitelli et al.: Emodin-Induced Eryptosis}

96 Lupescu A, Bissinger R, Goebel T, Salker MS, Alzoubi K, Liu G, Chirigiu L, Mack AF, Qadri SM, Lang F: Enhanced suicidal erythrocyte death contributing to anemia in the elderly. Cell Physiol Biochem 2015;36:773-783.

97 Lupescu A, Bissinger R, Herrmann T, Oswald G, Jilani K, Lang F: Induction of suicidal erythrocyte death by novobiocin. Cell Physiol Biochem 2014;33:670-680.

98 Lupescu A, Bissinger R, Warsi J, Jilani K, Lang F: Stimulation of erythrocyte cell membrane scrambling by gedunin. Cell Physiol Biochem 2014;33:1838-1848.

99 Malik A, Bissinger R, Calabro S, Faggio C, Jilani K, Lang F: Aristolochic Acid Induced Suicidal Erythrocyte Death. Kidney Blood Press Res 2014;39:408-419.

100 Officioso A, Alzoubi K, Manna C, Lang F: Clofazimine Induced Suicidal Death of Human Erythrocytes. Cell Physiol Biochem 2015;37:331-341.

101 Oswald G, Alzoubi K, Abed M, Lang F: Stimulation of suicidal erythrocyte death by ribavirin. Basic Clin Pharmacol Toxicol 2014;114:311-317.

102 Peter T, Bissinger R, Enkel S, Alzoubi K, Oswald G, Lang F: Programmed erythrocyte death following in vitro Treosulfan treatment. Cell Physiol Biochem 2015;35:1372-1380.

103 Stockinger K, Bissinger R, Bouguerra G, Abbes S, Lang F: Enhanced Eryptosis Following Exposure to Carnosic Acid. Cell Physiol Biochem 2015;37:1779-1791.

104 Tesoriere L, Attanzio A, Allegra M, Cilla A, Gentile C, Livrea MA: Oxysterol mixture in hypercholesterolemiarelevant proportion causes oxidative stress-dependent eryptosis. Cell Physiol Biochem 2014;34:10751089.

105 Waibel S, Bissinger R, Bouguerra G, Abbes S, Lang F: Saquinavir Induced Suicidal Death of Human Erythrocytes. Cell Physiol Biochem 2015;37:1973-1982.

106 Zierle J, Bissinger R, Egler J, Lang F: Lapatinib Induced Suicidal Death of Human Erythrocytes. Cell Physiol Biochem 2015;37:2275-2287.

107 Bissinger R, Bouguerra G, Al Mamun Bhuyan A, Waibel S, Abbes S, Lang F: Efavirenz Induced Suicidal Death of Human Erythrocytes. Cell Physiol Biochem 2015;37:2496-2507.

108 Bissinger R, Waibel S, Bouguerra G, Al Mamun Bhuyan A, Abbes S, Lang F: Enhanced Eryptosis Following Exposure to Lopinavir. Cell Physiol Biochem 2015;37:2486-2495.

109 Briglia M, Calabro S, Signoretto E, Alzoubi K, Laufer S, Faggio C, Lang F: Fucoxanthin Induced Suicidal Death of Human Erythrocytes. Cell Physiol Biochem 2015;37:2464-2475.

110 Briglia M, Fazio A, Faggio C, Lang F: Triggering of Suicidal Erythrocyte Death by Zosuquidar. Cell Physiol Biochem 2015;37:2355-2365.

111 Fazio A, Briglia M, Faggio C, Alzoubi K, Lang F: Oxaliplatin Induced Suicidal Death of Human Erythrocytes. Cell Physiol Biochem 2015;37:2393-2404.

112 Macczak A, Cyrkler M, Bukowska B, Michalowicz J: Eryptosis-inducing activity of bisphenol A and its analogs in human red blood cells (in vitro study). J Hazard Mater 2016;307:328-335.

113 Officioso A, Alzoubi K, Lang F, Manna C: Hydroxytyrosol inhibits phosphatidylserine exposure and suicidal death induced by mercury in human erythrocytes: Possible involvement of the glutathione pathway. Food Chem Toxicol 2016;89:47-53.

114 Officioso A, Manna C, Alzoubi K, Lang F: Bromfenvinphos induced suicidal death of human erythrocytes. Pestic Biochem Physiol 2016;126:58-63.

115 Qadri SM, Donkor DA, Bhakta V, Eltringham-Smith LJ, Dwivedi DJ, Moore JC, Pepler L, Ivetic N, Nazi I, Fox-Robichaud AE, Liaw PC, Sheffield WP: Phosphatidylserine externalization and procoagulant activation of erythrocytes induced by Pseudomonas aeruginosa virulence factor pyocyanin. J Cell Mol Med 2016;10.1111/jcmm.12778

116 Zierle J, Bissinger R, Bouguerra G, Abbes S, Lang F: Triggering of Suicidal Erythrocyte Death by Regorafenib. Cell Physiol Biochem 2016;38:160-172.

117 Pagano M, Faggio C: The use of erythrocyte fragility to assess xenobiotic cytotoxicity. Cell Biochem Funct 2015;33:351-355.

118 Silva-Herdade AS, Andolina G, Faggio C, Calado A, Saldanha C: Erythrocyte deformability - A partner of the inflammatory response. Microvasc Res 2016;107:34-38.

119 Liu Z, Wei F, Chen LJ, Xiong HR, Liu YY, Luo F, Hou W, Xiao H, Yang ZQ: In vitro and in vivo studies of the inhibitory effects of emodin isolated from Polygonum cuspidatum on Coxsakievirus B(4). Molecules 2013;18:11842-11858. 


\section{Cellular Physiology Cell Physiol Biochem 2016;40:91-103 and Biochemistry Published online: November 18, 2016 \begin{tabular}{l|l} 
DOI: 10.1159/000452527 & $\begin{array}{l}\text { (c) } \\
\text { www.karger.com/cpb }\end{array}$
\end{tabular} \\ Mischitelli et al.: Emodin-Induced Eryptosis}

120 Harrison HE, Bunting H, Ordway NK, Albrink WS: The Pathogenesis of the Renal Injury Produced in the Dog by Hemoglobin or Methemoglobin. J Exp Med 1947;86:339-356.

121 Abed M, Feger M, Alzoubi K, Pakladok T, Frauenfeld L, Geiger C, Towhid ST, Lang F: Sensitization of erythrocytes to suicidal erythrocyte death following water deprivation. Kidney Blood Press Res 2013;37:567-578.

122 Voelkl J, Alzoubi K, Mamar AK, Ahmed MS, Abed M, Lang F: Stimulation of suicidal erythrocyte death by increased extracellular phosphate concentrations. Kidney Blood Press Res 2013;38:42-51.

123 Abed M, Artunc F, Alzoubi K, Honisch S, Baumann D, Foller M, Lang F: Suicidal erythrocyte death in endstage renal disease. J Mol Med (Berl) 2014;92:871-879.

124 Ahmed MS, Langer H, Abed M, Voelkl J, Lang F: The uremic toxin acrolein promotes suicidal erythrocyte death. Kidney Blood Press Res 2013;37:158-167.

125 Polak-Jonkisz D, Purzyc L: Ca(2+) influx versus efflux during eryptosis in uremic erythrocytes. Blood Purif 2012;34:209-210; author reply 210.

126 Calderon-Salinas JV, Munoz-Reyes EG, Guerrero-Romero JF, Rodriguez-Moran M, Bracho-Riquelme RL, Carrera-Gracia MA, Quintanar-Escorza MA: Eryptosis and oxidative damage in type 2 diabetic mellitus patients with chronic kidney disease. Mol Cell Biochem 2011;357:171-179.

127 Lang PA, Beringer O, Nicolay JP, Amon O, Kempe DS, Hermle T, Attanasio P, Akel A, Schafer R, Friedrich B, Risler T, Baur M, Olbricht CJ, Zimmerhackl LB, Zipfel PF, Wieder T, Lang F: Suicidal death of erythrocytes in recurrent hemolytic uremic syndrome. J Mol Med (Berl) 2006;84:378-388.

128 Nicolay JP, Schneider J, Niemoeller OM, Artunc F, Portero-Otin M, Haik G, Jr., Thornalley PJ, Schleicher E, Wieder T, Lang F: Stimulation of suicidal erythrocyte death by methylglyoxal. Cell Physiol Biochem 2006;18:223-232.

129 Lang E, Gatidis S, Freise NF, Bock H, Kubitz R, Lauermann C, Orth HM, Klindt C, Schuier M, Keitel V, Reich M, Liu G, Schmidt S, Xu HC, Qadri SM, Herebian D, Pandyra AA, Mayatepek E, Gulbins E, Lang F, Haussinger D, Lang KS, Foller M, Lang PA: Conjugated bilirubin triggers anemia by inducing erythrocyte death. Hepatology 2015;61:275-284.

130 Kempe DS, Akel A, Lang PA, Hermle T, Biswas R, Muresanu J, Friedrich B, Dreischer P, Wolz C, Schumacher U, Peschel A, Gotz F, Doring G, Wieder T, Gulbins E, Lang F: Suicidal erythrocyte death in sepsis. J Mol Med (Berl) 2007;85:273-281.

131 Lang PA, Schenck M, Nicolay JP, Becker JU, Kempe DS, Lupescu A, Koka S, Eisele K, Klarl BA, Rubben H, Schmid KW, Mann K, Hildenbrand S, Hefter H, Huber SM, Wieder T, Erhardt A, Haussinger D, Gulbins E, Lang F: Liver cell death and anemia in Wilson disease involve acid sphingomyelinase and ceramide. Nat Med 2007;13:164-170.

132 Andrews DA, Low PS: Role of red blood cells in thrombosis. Curr Opin Hematol 1999;6:76-82.

133 Closse C, Dachary-Prigent J, Boisseau MR: Phosphatidylserine-related adhesion of human erythrocytes to vascular endothelium. Br J Haematol 1999;107:300-302.

134 Gallagher PG, Chang SH, Rettig MP, Neely JE, Hillery CA, Smith BD, Low PS: Altered erythrocyte endothelial adherence and membrane phospholipid asymmetry in hereditary hydrocytosis. Blood 2003;101:46254627.

135 Pandolfi A, Di Pietro N, Sirolli V, Giardinelli A, Di Silvestre S, Amoroso L, Di Tomo P, Capani F, Consoli A, Bonomini M: Mechanisms of uremic erythrocyte-induced adhesion of human monocytes to cultured endothelial cells. J Cell Physiol 2007;213:699-709.

136 Wood BL, Gibson DF, Tait JF: Increased erythrocyte phosphatidylserine exposure in sickle cell disease: flowcytometric measurement and clinical associations. Blood 1996;88:1873-1880.

137 Borst O, Abed M, Alesutan I, Towhid ST, Qadri SM, Foller M, Gawaz M, Lang F: Dynamic adhesion of eryptotic erythrocytes to endothelial cells via CXCL16/SR-PSOX. Am J Physiol Cell Physiol 2012;302:C644-C651.

138 Chung SM, Bae ON, Lim KM, Noh JY, Lee MY, Jung YS, Chung JH: Lysophosphatidic acid induces thrombogenic activity through phosphatidylserine exposure and procoagulant microvesicle generation in human erythrocytes. Arterioscler Thromb Vasc Biol 2007;27:414-421.

139 Zwaal RF, Comfurius P, Bevers EM: Surface exposure of phosphatidylserine in pathological cells. Cell Mol Life Sci 2005;62:971-988. 